\title{
https://doi.org/10.46813/2020-130-115 \\ FUNCTIONAL PROTECTIVE ZrN COATINGS ON IMPLANTS FOR TRAUMA SURGERY
}

\author{
V.S. Taran ${ }^{1}$, I.E. Garkusha ${ }^{1,3}$, A.V. Taran, ${ }^{1}$ R.M. Muratov ${ }^{1}$, P.M. Vorontsov $^{2}$,

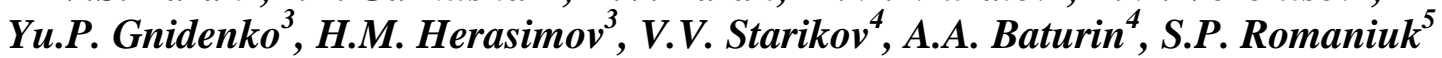 \\ ${ }^{1}$ Institute of Plasma Physics NSC “Kharkov Institute of Physics and Technology”, Kharkiv, Ukraine; \\ ${ }^{2}$ Sytenko Institute of Spine and Joint Pathology, NAMS, Kharkiv, Ukraine, \\ ${ }^{3}$ V.N. Karazin Kharkiv National University, Kharkiv, Ukraine; \\ ${ }^{4}$ National Technical University "Kharkiv Polytechnic Institute”, Kharkiv, Ukraine; \\ ${ }^{5}$ Kharkiv Petro Vasylenko National Technical University of Agriculture, Kharkiv, Ukraine
}

\section{E-mail:avtaran@ukr.net}

The nano-crystalline films of zirconium nitride have been synthesized on implants for trauma surgery made of AISI 316 L stainles steel by using vacuum-arc deposition under RF-biasing mode in "Bulat" type device. Structure examinations - X-ray diffraction analysis (XRD), X-ray fluoriscent analysis (XRF), scanning electron microscopy (SEM) with microanalysis (EDX), nanoidentation method - were performed to study phase and chemical composition, surface morphology, microstructure and nanohardness of $\mathrm{ZrN}$ coatings. The corrosion resistance of coatings has been tested in $0.9 \%$ quasiphysiological $\mathrm{NaCl}$ solution.

PACS: $81.40 .-\mathrm{Z}$

\section{INTRODUCTION}

Metallic biomaterials such as Ti6Al4V alloys, 316L stainless steel and $\mathrm{Co}-\mathrm{Cr}$ alloys are being used as artificial joints, dental abatements, orthopedic fixation, and stents bone fixation devices [1-3]. Ti6Al4V alloy has excellent mechanical properties, corrosion resistance and super plasticity. However, Ti6Al4V contains aluminum and vanadium which are toxic elements and very harmful to human bodies. AISI $316 \mathrm{~L}$ stainless steel (SS) does not have the required level of bioinerticity due to high nickel content whereas $\mathrm{Co}$ in long term $\mathrm{Co}-\mathrm{Cr}$ alloys has cancerogenic effect [4-6]. Low mechanical properties and stress corrosion have been reported for implants fabricated from AISI 316 L [7]. All biomaterials have to satisfy various criteria, such as strength, high corrosion resistance, bioadhesion, biocompatibility, high wear resistance, and low friction coefficient [8].

Non-corrosive behavior in tissue-material interface is one of the most important criteria for bio-metallic implants [9]. The implanted material is exposed to body fluids, such as intercellular fluid and blood depending on the surrounding tissue. Body fluid consists of inorganic ions $\left(\mathrm{Na}^{+}, \mathrm{Cl}^{-}\right.$, etc), amino acids, proteins, and organic acids [9].

Manufacturing of implants from medical stainless steel with additional biocompatible coatings based on composite materials, titanium, zirconium and their nitrides, oxides, allows to significantly reducing the occurrence of infiltrates in the human body. Bioinertness of structures from such elements is four times better than that of medical stainless steel. Among these $\mathrm{ZrN}$ is also considered as biocompatible coating for various implants and coatings for surgical instruments.

Zirconium nitride $(\mathrm{ZrN})$ ceramic with cubic structure has high wear, fatigue and corrosion resistance properties and is widely used as hard, refractory and bioinert coating in industry and medicine. It was reported that $\mathrm{ZrN}$ coating showed better corrosion resistance then TiN coating $[10,11]$. Stoichiometric $\mathrm{ZrN}$ has only stable phase with a gold-like color due to its metallic band structure.

Plasma based PVD coatings have favorable residual stresses, higher density and better adhesion compared to other techniques. PVD technology modifies the surface properties of tools without changing the underlying material properties and biomechanical functionality. One of the drawbacks of this method is formation of macroparticles by the ejected molten droplets from the hot cathode spot by higher plasma pressure within the cathode spot. The composition of these particles being completely different from the rest of the coatings, these particles also offer the local source of variation in physical and mechanical properties. It was shown in our experiments $[12,13]$ that the utilization of vacuum-arc evaporation with RF discharge allows applying coatings onto dielectrics and thermo-liable instrument at room temperature decreasing the amount of macro-particles emitted from plasma flow.

In the present research, the nano-crystalline films of zirconium nitride have been synthesized on implants for trauma surgery made of AISI $316 \mathrm{~L}$ stainless steel. The corrosion resistance of coatings has been tested in $0.9 \%$ quasiphysiological $\mathrm{NaCl}$ solution.

\section{EXPERIMENTAL SETUP}

$\mathrm{ZrN}$ coatings were synthesized on plates for osteosynthesis made of AISI $316 \mathrm{~L} \mathrm{SS}$ by using the vacuum-arc method with RF discharge in a "Bulat-6" type device (Fig.1). Bias potential was applied to the sample holder from the RF generator operated at $5 \mathrm{MHz}$. Chemically pure zirconium (at purity $99.999 \%$ ) was used as cathode material. Nitrogen $(99.99 \%)$ was used as an active gas. Before deposition, the substrates were pre- 
cleaned in an ultrasonic bath for $10 \mathrm{~min}$. Surface cleaning (substrate degreasing and removing impurities) in the RF discharge was carried out in an argon plasma for $15 \mathrm{~min}$ $\left(\mathrm{U}_{\text {bias }}=1 \mathrm{kV}, \mathrm{P}(\mathrm{A})=0.6 \mathrm{~Pa}\right)$. A $\mathrm{Zr}$ buffer layer of $20 \mathrm{~nm}$ thickness was deposited before the nitride coating to improve coating adhesion, using $\mathrm{I}_{\mathrm{arc}}=110 \mathrm{~A}, \mathrm{U}(\mathrm{RF})$ bias $=-200 \mathrm{~V}$, base pressure $\mathrm{P}=5 \cdot 10^{-3}$ bar and deposition time was $20 \mathrm{~min}$.

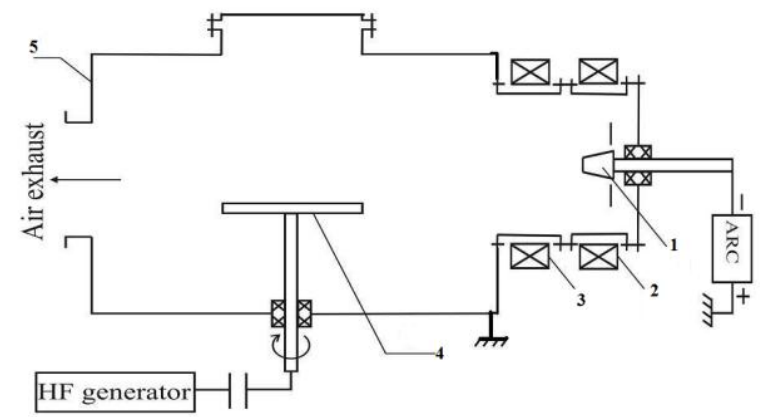

Fig.1. Scheme of the experimental equipment:

1 - plasma source; 2, 3 -electromagnetic coils; 4 - sample holder; 5 -vacuum chamber

The surface topography of the coating was studied using JEOL JSM-6390LV scanning electron microscope (SEM) with an accelerating voltage of $20 \mathrm{kV}$. Elemental composition was examined using EDX analysis. X-ray diffraction (XRD) analyses were performed using DRON-3M device, under $\mathrm{Cu}-\mathrm{K} \alpha$ radiation. Energydispersive spectrometer SPRUT-K (AO Ukrrentgen, Ukraine) was used for X-ray fluorescent analysis. Film thickness was determined by XRF examinations and comprised $\sim 2.2 \mu \mathrm{m}$. The measurement of nonohardness was carried out with a Nanoindenter G200 nanoindentor from the USA, using Berkovich diamond triangular pyramid. 7 probes were applied on the sample at a distance of $15 \mu \mathrm{m}$ from each other and the results were averaged.

The electrochemical activity (corrosion properties) of the $\mathrm{ZrN}$ coatings was determined by the values of their electrode potentials (reference electrode: $\mathrm{AgCl}$ ). The measurements were carried out in an electrochemical cell filled with $0.9 \%$ w/w aqueous $\mathrm{NaCl}$ (quasi-physiological solution).

\section{RESULTS AND DISCUSSION}

\subsection{SURFACE MORPHOLOGY AND CHEMICAL COMPOSITION}

The images of $\mathrm{ZrN}$ coated implants are shown in Fig. 2. The surface morphology of $\mathrm{ZrN}$ coated samples was examined by using light optical and scanning electron microscopy (Figs. 3, 4). The surface of the coating is cellular with so-called "honey-comb" type structure with a cell size of $0.2 \ldots 2 \mu \mathrm{m}$ with low amount of macroparticles.

In Fig. 4,b, SEM cross-section revealed the formation of dense structure with columnar grain growth, typical for transition metal nitrides such as TiN, $\mathrm{ZrN}$, and $\mathrm{CrN}$. Thin $\mathrm{Zr}$ buffer layer is also clearly distinguished in Fig. 4,b.

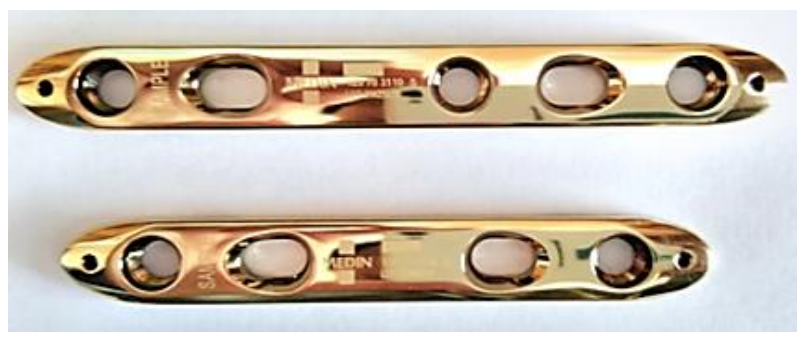

Fig. 2. General views of implants (plates) for trauma surgery with ZrN coatings

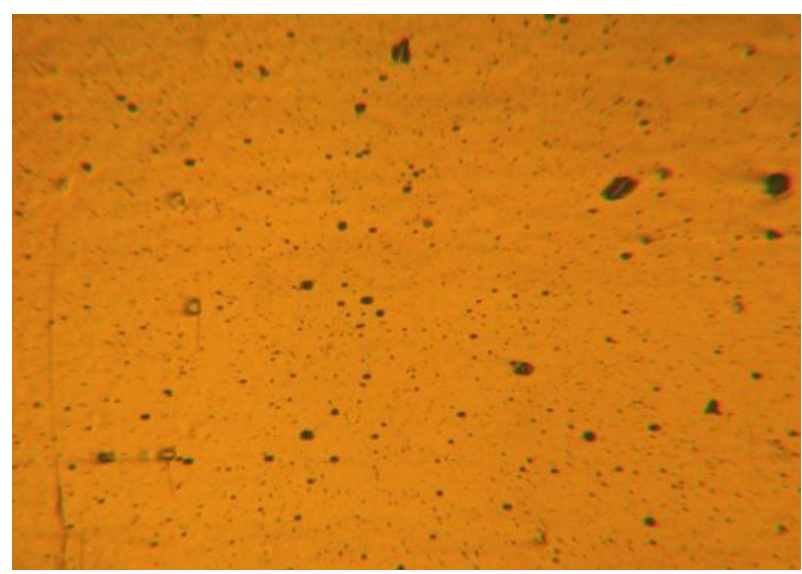

Fig. 3. Light optical image of ZrN coating on implant under magnification, $\times 100$
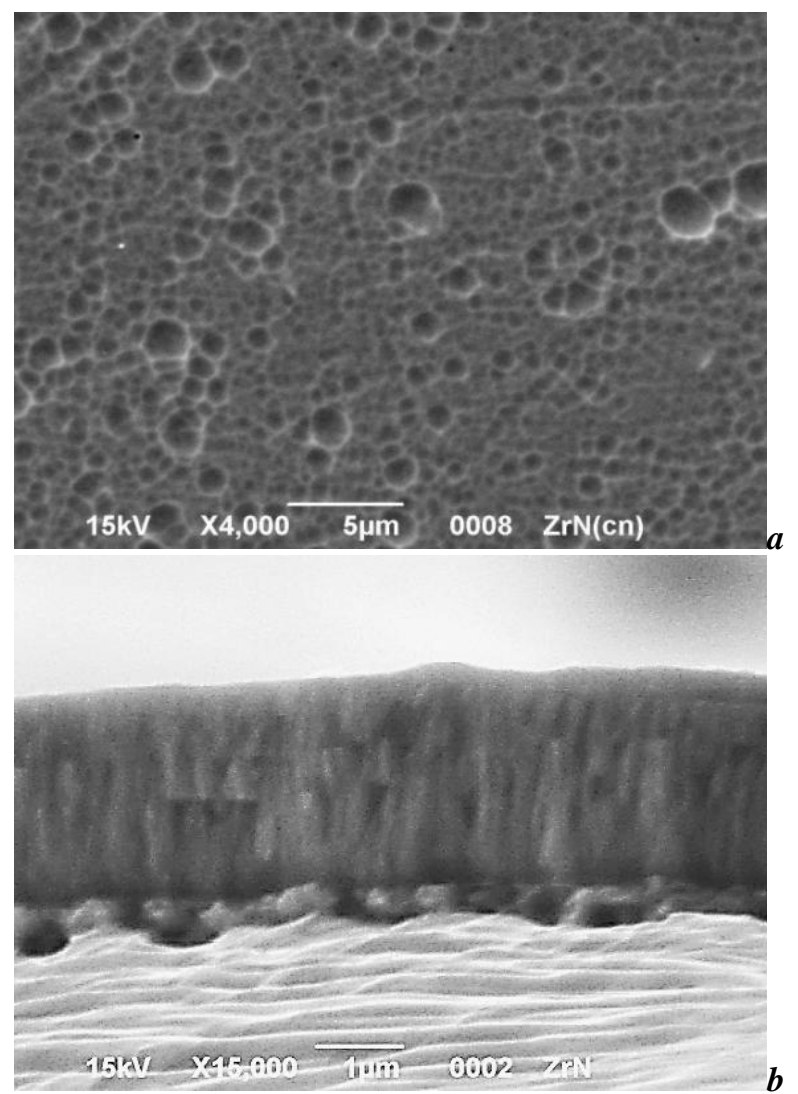

Fig. 4. SEM image (a) and cross-section (b) of ZrN coating on implant made of 316 L SS

A typical XRD pattern of $\mathrm{ZrN}$ coating is presented in Fig. 5. All angles of diffraction peaks were indexed as $\mathrm{ZrN}$ phase with a crystal structure of $\mathrm{B} 1 \mathrm{NaCl}$ cubic lattice type (according to ICDD 96-101-1362, 
$a=0.4577 \mathrm{~nm}$ lattice parameter). The average grain size calculated from the full-width-at-half-maximum (FWHM) intensity was $16 \mathrm{~nm}$ confirming the formation of nano-crystalline structure.

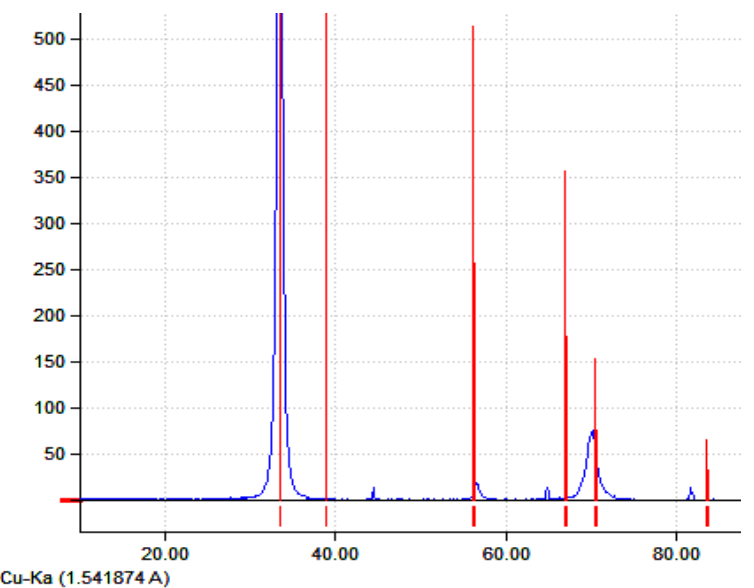

Fig. 5. XRD pattern for ZrN coating grown on stainless steel implant

According to the EDX data the relative contents of elements in the coatings were $78 \mathrm{wt} \% \mathrm{Zr}$, and 16 wt. $\% \mathrm{~N}, 2 \ldots 3 \mathrm{wt} . \% \mathrm{O}$ and $5 \mathrm{wt} . \% \mathrm{C}$. The presence of a small amount of oxygen and carbon is due both to residual gas incorporated in the chamber walls and to the contamination during sample handling in open atmosphere before the composition analysis.

\subsection{MECHANICAL PROPERTIES}

The results of studies of the hardness and elastic modulus of $\mathrm{ZrN}$ coatings are shown in Table. The average value of hardness and modulus of elasticity was: $\mathrm{H}=29 \mathrm{GPa} ; \mathrm{E}=319 \mathrm{GPa}$. Plasticity index $H / E$ and the ratio $\mathrm{H}^{3} / \mathrm{E}^{*^{2}}$ (where $\mathrm{E}^{*}=\mathrm{E} /\left(1-\mu^{2}\right)-$ the effective elastic modulus; $\mu$ - Poisson's ratio) are qualitative comparative characteristics of material plastic deformation resistance. The shear modulus $(\mathrm{G})$ and yield stress $\left(\sigma_{\mathrm{T}}\right)$ are defined as: $\mathrm{G}=\mathrm{E} / 2 \times(1+\mu)$ and $\sigma_{\mathrm{T}}=\mathrm{H} \mu / 3$.

The results of ZrN coating mechanical test

\begin{tabular}{|c|c|c|c|c|c|c|}
\hline № & E, GPa & H, GPa & $\mathrm{H} / \mathrm{E}$ & $\mathrm{H}^{3} / \mathrm{E}^{\text {*2 }}$ & $\mathrm{G}, \mathrm{GPa}$ & $\begin{array}{c}\sigma_{\mathrm{T}}, \\
\mathrm{GPa}\end{array}$ \\
\hline 1 & 335 & 31 & 0.092 & 0.233 & 210.19 & 10.36 \\
\hline 2 & 333 & 31 & 0.095 & 0.249 & 208.42 & 10.53 \\
\hline 3 & 289 & 26 & 0.090 & 0.188 & 180.38 & 8.70 \\
\hline 4 & 301 & 25 & 0.088 & 0.182 & 188.77 & 8.88 \\
\hline 5 & 317 & 30 & 0.092 & 0.218 & 197.73 & 9.73 \\
\hline 6 & 332 & 29 & 0.088 & 0.198 & 207.29 & 9.71 \\
\hline 7 & 338 & 32 & 0.095 & 0.254 & 210.77 & 10.68 \\
\hline & $\mathbf{3 1 9}$ & $\mathbf{2 9}$ & $\mathbf{0 . 0 9 2}$ & $\mathbf{0 . 2 1 7}$ & $\mathbf{2 0 0 . 5 0 6}$ & $\mathbf{9 . 7 9 8}$ \\
\hline
\end{tabular}

The increase in the hardness of coatings obtained by deposition uner RF biasing mode is related, first of all, to the grinding of the grain structure of the coatings (the Hall-Petch rule). The factor of compressive internal stresses that always occur in coatings deposited at low substrate temperatures under such deposition conditions cannot be excluded. We also speculate that a pulsed plasma is not only a source of substance and energy, but also under certain conditions, it manifests itself as a powerful matter structurizer.

\subsection{CORROSION PROPERTIES}

The electrode potential of the pure implant was $34 \mathrm{mV}$ (Fig. 6, curve 1). The $\mathrm{ZrN}$ coating passivates the surface and increases the potential to a value of $+25 \mathrm{mV}$ (see Fig. 6, curve 2). This means that there are no through pores in the coating confirming good passivation properties. We assume that application of $\mathrm{Zr}$ buffer layer can also alter adhesion and may interrupt the pinhole connection through the coating surface to the underlying substrate, therefore reducing the exposure area of the substrate to the electrolyte.

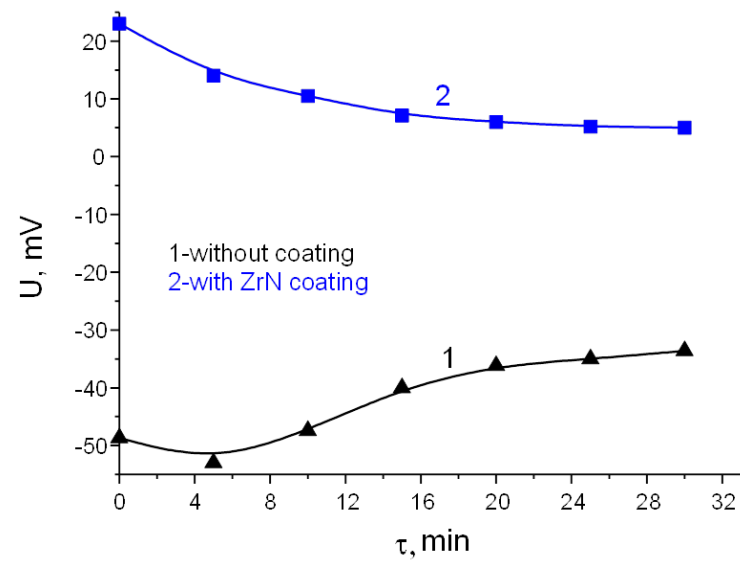

Fig. 6. Corrosion tests in $0.9 \%$ quasiphysiological $\mathrm{NaCl}$ solution

\section{CONCLUSIONS}

1. ZrN coatings have been deposited onto AISI 316 L implants for trauma surgery by using vacuum-arc deposition under RF biasing mode.

2. XRD data revealed the formation of stoichiometric $\mathrm{ZrN}$ phase of cubic modification with average grain size of $16 \mathrm{~nm}$.

3. The average value of nanohardness comprised $29 \mathrm{GPa}$ with elastic modulus $319 \mathrm{GPa}$.

4. The electrode potential of the coated implant was significantly improved than that of the uncoated stainless steel implant confirming good passivation properties.

5. The $\mathrm{Zr}$ buffer layer improves mismatch of the $\mathrm{ZrN}$ coating and the stainless steel substrate and may interrupt the pin-hole corrosion.

6. The obtained results would be perspective for applying functional protective $\mathrm{ZrN}$ coating on implants to reduce Ni induced corrosion.

\section{REFERENCES}

1. J. Park, R.S. Lakes. Biomaterials an Introduction. 3rd ed. Springer: «Berlin/Heidelberg», Germany, 2007.

2. M. Niinomi et al. Metallic biomaterials // J. Artif. Organs. 2008, v. 11, p. 105-110.

3. M. Karanjai, G.V.N. Sundaresan, et al. Development of titanium based biocomposite by powder metallurgy 
processing with in situ forming of $\mathrm{Ca}-\mathrm{P}$ phases // Mat. Sci. Eng. A. 2007, v. 447, p. 19-26.

4. O. Yoshimitsu, G. Emiko, et al. Comparison of metal release from various metallic biomaterials in vitro // Biomaterials. 2005, v. 26, p. 11-21.

5. S. Nag, R. Banerjee, H.L. Fraser. Microstructural evolution and strengthening mechanisms in Ti-Nb-ZrTa, Ti-Mo-Zr-Fe and Ti-15Mo biocompatible alloys // Mater. Sci. Eng. C. 2005, v. 25, p. 357-362.

6. D.B. McGregor, R.A. Baan, C. Partensky, J.M. Rice, J.D. Wibourn. Evaluation of the carcinogenic risks to humans associated with surgical implants and other foreign bodies-a report of an IARC monographs programmed meeting // Eur. J. Cancer. 2000, v. 36, p. 307-313.

7. M. Niinomi et al. Recent metallic materials for biomedical applications // Metall. Mater. Trans. A. 2002, v. 33, p. 477-486.

8. Mohamed A. Hussein, Abdul Samad Mohammed, and Naser Al-Aqeeli. Wear Characteristics of Metallic
Biomaterials: A Review // Materials. 2015, v. 8, p. 2749-2768.

9. Bio-Corrosion Study of Ti6Al4V and S.S 316L Medical Grade Alloys in DMEM Medium Culture: in vitro Conference Paper 2013 DOI: 10.13140/RG.2.1.1824.0165 International Conference on New and Advanced Materials (NAMIC 2013).

10. R. Hubler, A. Cozza, T.L. Marcondes, R.B. Souza, F.F. Fiori // Surf. Coat. Technol. 2001, v. 142(1), p. 1078 .

11. Wen-Jun Chou, Ge-Ping Yu, Jia-Hong Huang // Surf. Coat. Technol. 2003, v. 167(1), p. 59-70.

12. A.V. Taran, I.E. Garkusha, V.S. Taran, et al. // J. Adv. Microsc. Res. 2018, v. 13, p. 313-319.

13. A.V. Taran, I.E. Garkusha, V.S. Taran, et al. // Problems of Atomic Science and Technology. Series: «Plasma Physics» (25). 2019, № 1, p. 243-247.

Article received 15.09.2020

\title{
ФУНКЦИОНАЛЬНЫЕ ЗАЩИТНЫЕ ПОКРЫТИЯ ZrN НА ИМПЛАНТАХ ДЛЯ ТРАВМАТОЛОГИИ
}

\author{
В.С. Таран, И.Е. Гаркуша, А.В. Таран, Р.М. Муратов, П.М. Воронцов, Ю.П. Гниденко, \\ Г.Н. Герасимов, В.В. Стариков, А.А. Батурин, С.П. Романюк
}

Нанокристаллические пленки нитрида циркония были синтезированы на имплантах для травматологии, изготовленных из нержавеющей стали AISI $316 \mathrm{~L}$, с использованием вакуумно-дугового напыления в режиме ВЧ-смещения в установке “Булат". Структурные исследования - рентгеноструктурный анализ (XRD), рентгенофлуоресцентный анализ (XRF), сканирующая электронная микроскопия (SEM) c микроанализом (EDX), метод наноидентификации - были выполнены для изучения фазового и химического составов, морфологии поверхности, микроструктуры и нанотвердости покрытий ZrN. Коррозионная стойкость покрытий исследовалась в 0,9 \% квазифизиологическом растворе $\mathrm{NaCl}$.

\section{ФУНКЦІОНАЛЬН ЗАХИСНІ ПОКРИТТЯ ZrN НА ІМПЛАНТАХ ДЛЯ ТРАВМАТОЛОГЇ̈}

\section{В.С. Таран, І.С. Гаркуша, А.В. Таран, Р.М. Муратов, П.М. Воронцов, Ю.П. Гніденко, Г.М. Герасимов, В.В. Старіков, А.А. Батурин, С.П. Романюк}

Нанокристалічні плівки нітриду цирконію були синтезовані на імплантах для травматології, які виготовлені 3 нержавіючої сталі AISI $316 \mathrm{~L}$, за допомогою вакуумно-дугового осадження в режимі ВЧ-зміщення в установці типу “Булат”. Структурні дослідження - рентгенівський дифракційний аналіз (XRD), рентгенівський флуоресцентний аналіз (XRF), скануюча електронна мікроскопія (SEM) 3 мікроаналізом (EDX), метод наноідентифікації - були виконані для вивчення фазового та хімічного складів, морфології поверхні, мікроструктури та нанотвердості покриттів ZrN. Корозійну стійкість покриттів було досліджено в 0,9\% квазіфізіологічному розчині $\mathrm{NaCl}$. 